\title{
GCU
}

Glasgow Caledonian

University

University for the Common Good

\section{Are social innovation paradigms incommensurable?}

Montgomery, Tom

Published in:

Voluntas: International Journal of Voluntary and Nonprofit Organizations

DOI:

10.1007/s11266-016-9688-1

Publication date:

2016

Document Version

Publisher's PDF, also known as Version of record

Link to publication in ResearchOnline

Citation for published version (Harvard):

Montgomery, T 2016, 'Are social innovation paradigms incommensurable?', Voluntas: International Journal of Voluntary and Nonprofit Organizations, vol. 27, pp. 1979-2000. https://doi.org/10.1007/s11266-016-9688-1

\section{General rights}

Copyright and moral rights for the publications made accessible in the public portal are retained by the authors and/or other copyright owners and it is a condition of accessing publications that users recognise and abide by the legal requirements associated with these rights.

Take down policy

If you believe that this document breaches copyright please view our takedown policy at https://edshare.gcu.ac.uk/id/eprint/5179 for details of how to contact us. 


\title{
Are Social Innovation Paradigms Incommensurable?
}

\author{
Tom Montgomery ${ }^{1}$
}

Published online: 18 February 2016

(c) The Author(s) 2016. This article is published with open access at Springerlink.com

\begin{abstract}
This paper calls attention to the problematic use of the concept of social innovation which remains undefined despite its proliferation throughout academic and policy discourses. Extant research has thus far failed to capture the sociopolitical contentions which surround social innovation. This paper therefore draws upon the work of Thomas Kuhn and conducts a paradigmatic analysis of the field of social innovation which identifies two emerging schools: one technocratic, the other democratic. The paper identifies some of the key thinkers in each paradigm and explains how the struggle between these two paradigms reveals itself to be part of a broader conflict between neoliberalism and it opponents and concludes by arguing that future research focused upon local contextualised struggles will reveal which paradigm is in the ascendancy.
\end{abstract}

Résumé Cet article attire l'attention sur l'usage problématique de la notion d'innovation sociale qui reste indéfinie malgré sa prolifération dans tous les discours académiques et politiques. Les recherches existantes ont jusqu'à présent échoué à saisir les prétentions sociopolitiques autour de l'innovation sociale. Cet article s'appuie par conséquent sur les travaux de Thomas Kuhn et effectue une analyse paradigmatique du domaine de l'innovation sociale, qui identifie deux nouvelles écoles : l'une technocrate, l'autre démocratique. L'article identifie quelques-uns des principaux penseurs dans chaque paradigme et explique comment la lutte entre ces deux paradigmes se révèle faire partie d'un conflit plus large entre le néolibéralisme et ses opposants. Il conclut ensuite en affirmant que les recherches futures axées sur les luttes locales contextualisées révèleront le paradigme qui connait une popularité croissante.

Tom Montgomery

Thomas.Montgomery@gcu.ac.uk

1 Yunus Centre for Social Business \& Health, Glasgow Caledonian University, M201 George

Moore Building, Cowcaddens Road, Glasgow G4 0BA, UK 
Zusammenfassung Dieser Beitrag macht auf die problematische Verwendung des Konzepts der sozialen Innovation aufmerksam, das trotz seiner weiten Verbreitung in akademischen und politischen Diskursen noch immer nicht definiert ist. Forschungen haben es bislang versäumt, die sozio-politischen Behauptungen im Zusammenhang mit der sozialen Innovation $\mathrm{zu}$ erfassen. In der vorliegenden Abhandlung stützt man sich daher auf die Arbeit von Thomas Kuhn und führt eine paradigmatische Analyse des Bereichs soziale Innovation durch, wobei zwei neu entstehende Lehren ergründet werden: eine technokratische und eine demokratische. Für beide Modelle werden einige wichtige Denker identifiziert, und man erklärt, wie sich der Konflikt zwischen diesen beiden Modellen als Teil eines größeren Konflikts zwischen Neoliberalismus und seinen Gegnern enthüllt. Abschließend wird behauptet, dass zukünftige Forschungsarbeiten, welche sich auf lokale kontextbezogene Konflikte konzentrieren, zeigen werden, welches Modell dominiert.

Resumen El presente artículo llama la atención sobre el problemático uso del concepto de innovación social que sigue sin definirse a pesar de su proliferación en los discursos académicos y políticos. La investigación existente no ha logrado hasta ahora reflejar las cuestiones controvertidas sociopolíticas que rodean a la innovación social. Por consiguiente, el presente documento se nutre del trabajo de Thomas Kuhn y realiza un análisis paradigmático del campo de la innovación social que identifica dos escuelas emergentes: una tecnocrática, la otra democrática. El artículo identifica a algunos de los pensadores claves en cada paradigma y explica cómo la lucha entre estos dos paradigmas se revela formando parte de un conflicto más amplio entre el neoliberalismo y sus oponentes y concluye argumentando que investigaciones futuras centradas en luchas locales contextualizadas revelarán qué paradigma es el dominante.

Keywords Social innovation $\cdot$ Paradigm $\cdot$ Neoliberalism $\cdot$ Depoliticisation

\section{Introduction}

\section{The Undefined Concept}

The concept of social innovation has in recent years crept into the lexicon of academics, policymakers and practitioners despite a lack of common understanding regarding its meaning and its significance. A range of programmes and policy pronouncements on both sides of the Atlantic suggest that social innovation has entered the mainstream (Sinclair and Baglioni 2014). In the United States, the White House in 2009 created a dedicated Office of Social Innovation and Civic Participation ${ }^{1}$ to coordinate these activities. In the European Union, social innovation has become the focus not just of policymakers and practitioners but

\footnotetext{
${ }^{1}$ https://www.whitehouse.gov/administration/eop/sicp.
} 
has also resulted in a number of initiatives ${ }^{2}$ and large collaborative research projects. ${ }^{3}$ Used interchangeably with numerous other terms such as social economy, social enterprise, third sector and big society, it almost seems to teeter on the brink of definitional bankruptcy when in fact it is at the centre of an ideological battle between neoliberalism and its opponents.

The divisions created by the conflict over its definition reflect a broader realisation that "social innovation is never neutral but always political and socially constructed" (Nicholls and Murdock 2012, p. 4). The purpose of this paper is to examine how social innovation can be socially and politically constructed to defend or attack neoliberal hegemony, to accept or reject the technocratic governance of that hegemony and how it can be used to limit or liberate the social and political capacities of citizens. The analysis is inspired by those who recognise the need to build an "epistemology sensitive to the inevitable dialectics of struggle between forces pursuing radical social innovation oriented to social emancipation and those seeking to maintain an asymmetrically organized social order biased towards agencies of profit-making, efficient markets, and business-friendly social relations" (Jessop et al. 2013, p. 112). Such reflections provide a useful starting point but provoke more questions than answers; questions surrounding how these forces operationalise social innovation, if and how these forces interact and more fundamentally, whether or not it is possible to compare these different emergent schools of social innovation.

The contested conceptual space of social innovation is occupied by two factions whose protagonists adopt the same idioms and even demonstrate concern for the same issues, but speak past each other in ways that can best be explained by the fact that they operate in different paradigmatic worlds where the most basic assumptions are fundamentally opposed. This has brought us to the central question posed by this paper: are these paradigms of social innovation incommensurable? We cannot begin to answer this question without unpacking the concept of incommensurability which stems from the work of Thomas Kuhn (1962), whose analysis of scientific

\footnotetext{
2 These initiatives include

Social Innovation Europe (https://webgate.ec.europa.eu/socialinnovationeurope/about),

EU Social Innovation Competition (http://ec.europa.eu/enterprise/policies/innovation/policy/socialinnovation/competition/index_en.htm),

European Investment Bank Social Innovation Tournament (http://institute.eib.org/programmes/social/ social-innovation-tournament/frequently-asked-questions/),

Naples 2.0 Social Innovation Competition (http://www.euclidnetwork.eu/projects/completed-projects/ european-social-innovation-naples-20.html),

This Is European Social Innovation (http://www.euclidnetwork.eu/projects/completed-projects/this-iseuropean-social-innovation.html).

3 These projects include

Tepsie (http://www.tepsie.eu/),

Wilco (http://www.wilcoproject.eu/what-is-wilco/), ImPRovE (http://improve-research.eu/?page_id=5),

LIPSE (http://www.lipse.org/about),

Selusi (http://www.selusi.eu/index.php?page=about-the-project),

SocIEtY (http://www.society-youth.eu/society),

CrESSI (http://www.sbs.ox.ac.uk/faculty-research/research-projects/cressi).
} 
revolution refines our understanding of the development of the embryonic social innovation paradigms.

\section{Paradigmatic Analysis}

In identifying emerging paradigms of social innovation, it is perhaps important to acknowledge that the very definition of what a paradigm consists of has itself been the subject of some debate, as Masterman (1970) graphically illustrates by offering no less than twenty-one variations of the concept. However, the purpose of this paper is not to recreate that discussion; instead, we shall begin by simply restating Kuhn's concise position that a paradigm is at the fundament of science and is that which actually transforms a group "into a profession or, at least, a discipline" (Kuhn 1962, p. 19). Therefore, the members of these groups see the same things when collecting data; they will also use the same terminology, and given that the focus of these groups is to refine and improve the paradigm's capacity to solve problems, the tools which they use to achieve this aim are also constructed within the theoretical confines of the paradigm (Kuhn 1962). Although neither can be described as having completed the transition from a group into a discipline, we can identify two paradigms under construction which currently occupy the field of social innovation.

Just as Kuhn describes the social sciences as pre-paradigmatic, a similar assessment can be made of the construction of social innovation paradigms. Efforts have been made which illustrate the complexity of defining social innovation (Phills et al. 2008; Caulier-Grice et al. 2012; Unger 2015; Nicholls et al. 2015) and although the influence of Kuhn has already been apparent in some existing research (Nicholls 2010; Dawson and Daniel 2010; Cajaiba-Santana 2014), this overlooks the valuable concept of incommensurability which can illuminate our understanding of social innovation. Nevertheless, before addressing the concept of incommensurability in finer detail, we should remind ourselves of Kuhn's insistence that "any study of paradigm-directed or of paradigm-shattering research must begin by locating the responsible group or groups" (Kuhn 1970, p. 180). Therefore, we should begin by outlining the emerging schools of social innovation identified by this analysis.

There are currently two developing schools of social innovation engaged in a conflict over the very meaning of the concept (see Table 1). One school-the technocratic paradigm of social innovation-is a subgroup (Kuhn 1970) of neoliberalism, thus placing it at the advantage of being the favoured school of a hegemonic project which brings with it the support of powerful economic and

Table 1 Paradigms of social innovation

\begin{tabular}{lll}
\hline & Technocratic & Democratic \\
\hline Knowledge construction & Expert & Community \\
Effects & Depoliticising & Politicising \\
Power distribution & Vertical & Horizontal \\
\hline
\end{tabular}


political advocates who have recognised its capacity to be mobilised in order to shore up the broader neoliberal project. The other school—the democratic paradigm of social innovation - is advocated by opponents of neoliberalism who recognise in it a possibility for creating spaces in which alternatives to the neoliberal project can be pursued.

It is more difficult to identify the democratic school as a subgroup as it has a more fragmented inheritance which is made even more difficult to trace as it appears to reject the very practices described by Kuhn as those which enable the construction of a scientific community (see Moulaert and Van Dyck 2013; Moulaert et al. 2013; Jessop et al. 2013 and Ranciere 1991). Therefore, tempting as it may be to simply move towards a comparative evaluation of both approaches and somehow reach a definitive conclusion that one paradigm carries more potential to meet human needs than the other, there is an immediate question confronting us, raised by Kuhn's own theory: whether or not such an evaluation is actually possible or instead if these paradigms are incommensurable.

\section{Incommensurability}

The potential incommensurability-literally that which has no common measureof social innovation paradigms must be considered given Kuhn's description of how the battle between paradigms is not won by the strength of evidence; instead, it refers to a situation where the "proponents of competing paradigms practice their trades in different worlds... the two groups of scientists see different things when they look from the same point in the same direction" (Kuhn 1962, p. 149). Many have drawn comparisons between this description and a gestalt shift (Fig. 1, below), although Kuhn (1962) himself described such comparisons as misleading. Indeed as Sharrock and Read (2002) point out, in a visual gestalt people can switch back and forth from one to the other; however, Kuhn's theory implies that scientists can do this only once and that their choice is both permanent and defined by their paradigm. This emphasises the entrenched worlds inhabited by adherents of the technocratic and democratic social innovation schools, their very perception of social needs, problems and the pursuit of solutions are defined by their paradigm.

Fig. 1 The duck/rabbit gestalt

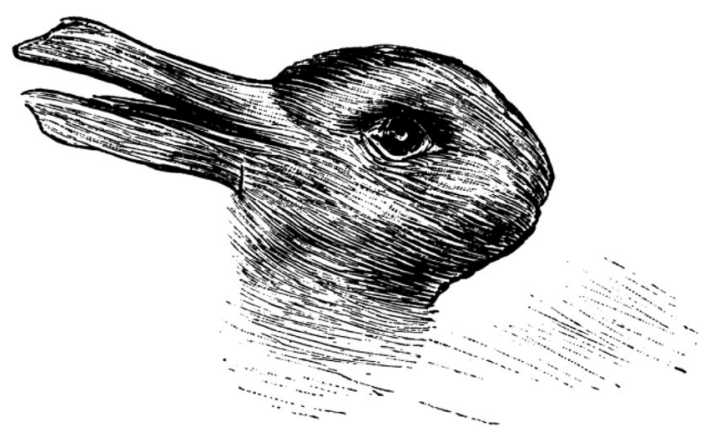


The idea that adherents of different paradigms operate in different worlds leads Kuhn (1962) to conclude that the only way for a scientist to fully understand a paradigm is to undergo a conversion, or paradigm shift, something which takes place within a period of conflict or scientific revolutions. This is a status which, through the course of this analysis, will be revealed as being particularly relevant to any discussion of social innovation. As will become clear, of particular significance is how Kuhn draws comparisons between the effects of a scientific revolution and a political revolution, in which he concludes that the absence of a shared capacity for evaluation means that "the parties to a revolutionary conflict must finally resort to the techniques of mass persuasion" (Kuhn 1962, p. 93). It is this conflict that we are witnessing in the field of social innovation amongst policymakers, practitioners and academics, and in order to better understand it, the first step should be to reveal the protagonists and their arguments. The schools outlined below-technocratic and democratic-encapsulate the characteristics and objectives of these nascent paradigms whilst forging the key points of contestation in a field which has been described as witnessing an absence of disagreement and even a "denial of politics" (Larrson and Brandsen 2016, p. 223).

\section{Technocratic Social Innovation}

\section{The Neoliberal Paradigm}

Policymakers in Europe have contributed towards the discursive construction of technocratic social innovation by positioning it within a free market frame. The language used when promoting social innovation reveals this to some extent and indeed the assertion outlined in the Guide to Social Innovation, produced by the European Commission provides us with a key example: "Europe has a head-start. It is ideally placed to take a lead and capture first-mover benefits when it comes to implementing social innovations" (European Commission 2013, p. 10). Therefore, some European policymakers are constructing a discourse which sets the agenda for social innovations to operate in terms of new markets and competition, a neoliberal disciplinary technique which provides a glimpse into a deeper relationship between the ideology of the free market and the technocratic school of social innovation.

The technocratic paradigm of social innovation cannot be fully understood without comprehending its relationship to neoliberalism. In a period of economic crisis, when the neoliberal project has come under intense scrutiny, the mobilisation of social innovation is a prime example of the deployment of "flanking mechanisms" (Brenner and Theodore 2002, p. 374), discourses and conducts directed towards civil society and designed to maintain the hegemony of the neoliberal faith, particularly when threatened with crisis and resistance. Moreover, when considering the roots of the neoliberal project, it becomes clear that the vague position occupied by the field of social innovation somewhere between the market and the state reflects some fundamental issues at the heart of the development of that project, where neoliberals agreed on what should be destroyed but not on what should be constructed, "this problem went back at least as far as Keynes' contention 
that Hayek was unable to demonstrate 'where to draw the line' on the role of the state in the economy" (Peck 2008, p. 26). Nevertheless, technocratic social innovation offers neoliberals a vehicle to complement their 'roll back' policies with 'roll out' initiatives (Peck and Tickell 2002), designed within a paradigm that solidifies neoliberal thinking in the blurred boundaries of the market and the state, whilst simultaneously stifling potential resistance to their hegemonic project.

The neoliberal support for the technocratic paradigm stems from its advocates being "increasingly concerned with the roll-out of new forms of institutional 'hardware"" (Peck and Tickell 2002, p. 389). Therefore, it is important to view this approach to social innovation as not just another site for neoliberalism to shore up its project but also as part of a broader "political project to reengineer the state" (Bockman 2012, p. 310). It is important at this point to emphasise that this 'reengineering' takes many different forms based on the socio-political context. Indeed just as neoliberalism is an incomplete, even messy project (Peck et al. 2010), so too is the emerging technocratic paradigm of social innovation which it supports and informs. As such, when observing the technocratic paradigm in action, we can expect it to reflect the methods of its theoretical base which "like an ideological parasite, neoliberalism both occupies and draws energy from its various host organisms" (Peck 2013, p. 144). Consequently, further research is required in order to explore in greater detail how this is operationalised in specific socio-political contexts; however, at this point it is possible to outline more sharply the processes by which social innovation is produced by the technocratic school.

Despite the continuous invocation of the term 'social' throughout the technocratic social innovation literature, it is frequently couched in terms which privilege market competition, with the 'social' repositioned within a commodified frame and an emphasis on 'supply and demand' as well as the potential for increased efficiency and savings that can be made to public finances (BEPA 2010; Murray et al. 2010; Mulgan 2006; Leadbeater and Meadway 2008). Nevertheless, Mulgan (2006) does attempt to construct a dichotomy between social innovation and other forms of innovation, highlighting that "social innovation refers to innovative activities and services that are motivated by the goal of meeting a social need and that are predominantly diffused through organisations whose primary purposes are social. Business innovation is generally motivated by profit maximisation and diffused through organisations that are primarily motivated by profit maximisation" (p. 146). However, this attempted clarification falls short of providing an effective distinction given the scope for interpretation when we consider the difficulties posed by attempting to identify the 'primary' motivations of organisations. As we have already clarified, this ambiguity inherent within the technocratic approach to social innovation reflects its neoliberal foundations.

In some areas, the ambiguity which the technocratic school occupies and thrives upon has already been the subject of extant research; one such area is that of social enterprise (for more on the definition of social enterprise see Pearce 2003; Borzaga and Defourny 2001; Teasdale 2012; Peredo and McLean 2006). Despite articulating anti-hierarchical rhetoric in order to attack the welfare state, this is quickly discarded when the technocratic school discuss the importance of social entrepreneurship. Indeed, it becomes readily apparent that one of common 
identifiers of the adherents to the technocratic paradigm is a reverence for the social entrepreneur, leading to assertions that "social innovation holds the key to our social ills. Social entrepreneurs are the people most able to deliver that innovation" (Leadbeater 1997, p. 20). The trope of the heroic entrepreneur being espoused by the technocratic school should not surprise us given their neoliberal inspiration.

One of the key theorists who has become a reference point for those wishing to perpetuate the discourse of the heroic entrepreneur in the economy is Joseph Schumpeter who asserts that to be considered one of these agents of change in the economy: "requires aptitudes that are present in only a small fraction of the population and that define the entrepreneurial type as well as the entrepreneurial function" (Schumpeter 2011, p. 132). Drawing upon Schumpeter's theory of creative destruction, the technocratic school inject the 'social' to naturalise the connection between the social entrepreneur and social innovation (Dees 2001), all of which is a recurring theme in the literature of that paradigm. The depiction of the dynamic social entrepreneur (Dees and Economy 2002) is mobilised to reinforce the discourses of the efficient market expert by the technocratic school; this adulation of expertise is not restricted to the economy, but it is also extended to government and nowhere is this more apparent than in the neoliberal forms of governance which are characterised by a privileging of technocracy.

\section{Technocratic Governance}

Technocratic social innovation is interwoven within the neoliberal governmentality of post-Fordism and thus when looking at the 'service delivery' mechanisms of some governments in Europe and beyond we can see that this approach to social innovation becomes a euphemism for more than just an opportunity to 'innovate'. Instead, it provides for the soft privatisation of services that were once the sole domain of the Keynesian welfare state. As Moulaert et al. (2013) observe, "SI is increasingly embraced as a 'new' approach to solving the crisis of the welfare state, by creating new jobs in the 'cheap' social economy and reorganizing the welfare system through commodification and privatization of some of its services and the more efficient restructure of others" (pp. 17-18). The focus on efficiency drives many of the discourses surrounding technocratic social innovation but so too does the convenient fiction that the inclusion of organisations from the third sector and social enterprise enables such efficiencies to be realised whilst serving to include and empower marginalised communities.

The importance of driving towards more 'efficient' public services is emphasised by the technocratic school as being a crucial response to the economic crisis, which has in turn provided a perfect opportunity to carry out such reforms. Therefore, technocratic social innovation is mobilised in ways similar to that described by Bunt et al. (2010) in their discussion paper Schumpeter Comes to Whitehall, where "many aspects of what now constitute public sector activity would be opened up to a wider range of social and community organisations and charities to deliver innovative, diverse approaches that respond to public demand" (Bunt et al. 2010, p. 19). The focus on the expansion of choice and the recasting of the role of the citizen as a consumer of public services is a familiar market trope (Osborne and 
Gaebler 1992; Hood 1991; Le Grand 2006) and may lead some to question how the neoliberal approach can be described as technocratic-this will be elaborated in greater detail below-but at this point we can at least begin to comprehend the relationship between the technocratic paradigm and broader neoliberal ideas.

The recruitment of social innovation in the incursion against public services epitomises the attraction of the technocratic paradigm for those seeking to maintain the neoliberal order as it provides an opportunity to synchronise roll-back and rollout neoliberalism under the more palatable rubric of efficiency, necessity and empowerment. This is achieved through "the mobilization of the 'little platoons' in the shape of (local) voluntary and faith-based associations in the service of neoliberal goals" (Peck and Tickell 2002, p. 390). Moreover, these 'little platoons' may co-operate with this agenda in the belief that they can achieve at least some change within a hegemonic neoliberal system. This may prove to be a valid tactic but it is accompanied by the risk of seeking to be an agent of change within a system, only to find later that participation in the system has changed the agent. This risk becomes all the more conspicuous when witnessing the pleas from the technocratic school for more private investment, payment by results and scaling-up, amongst a whole host of objectives which embed organisations in neoliberal discourses and conducts of competition.

One way in which the technocratic school exerts influence over the internal dynamics of organisations is to draw comparisons with organisations in the private sector. A prime example surrounds the seemingly perpetual concern of the technocrats regarding the capacity of organisations and initiatives to 'scale-up' their efforts in ways comparable to initiatives in the private sector. Naturally, the solutions to such problems are also to be found within the framework of the market. Thus, the problem of scaling-up is reconfigured into a problem caused by a lack of funding and leads to some such as BEPA (2010) lamenting that "social ventures" experience unique challenges in terms of scaling-up and "ultimately this leads to a lack of funding for social entrepreneurs and a fragile market for valuing social innovation, which means that special forms of seed funding are needed to promote and test pilot cases" (p. 103). From here we can see how such concerns can lead to the emergence of new and 'innovative' forms of funding such as social impact bonds (SIBs) which position socially innovative organisations as service providers, enmeshed within a 'payment by results' system with a specific view towards tapping into the experience of those from a private investment background in sourcing funding for these organisations (for a critical discussion of SIBs and social investment see McHugh et al. 2013; Dowling and Harvie 2014).

Therefore, just as Kuhn (1962) explains that the paradigm determines the puzzles which are to be solved, the technocratic paradigm has determined that one puzzle to be solved in social innovation is the issue of scaling-up (Mulgan 2007; Schwab Foundation 2013; Gabriel 2014). The solution is then also found within the same paradigm, private sector funding, but this goes even further, because the emphasis on investment inevitably leads to discussions surrounding the potential 'returns on investment' that are possible from the results achieved and how such results and returns may be calculated. 
Calculating the returns on investment in social innovation is a key characteristic of the technocratic paradigm, marked by anxieties that "measuring the production (impact) of social innovation is a priority for policymaking as 'what you do not measure, you do not achieve'. However, the value produced does not easily translate into quantifiable benefits" (BEPA 2010, p. 55). As a consequence, there have been determined efforts to construct the apparatus necessary to meet these anxieties, such as the Social Return on Investment (SROI) which aims to provide the data required by policymakers and investors (Nicholls et al. 2009; Reeder et al. 2012) as well as the emergence of initiatives such as the Social Stock Exchange. ${ }^{4}$ All of which helps further entrench organisations within the frame of market discipline which dominates the discourses of the technocratic paradigm. Therefore, despite being seemingly displaced and disguised by the rhetoric of efficiency, necessity and empowerment, what becomes increasingly apparent is that the technocratic paradigm of social innovation represents the more acceptable face of neoliberalism, which instead of hair shirt austerity and public sector retrenchment, evokes "a feel-good emphasis on human and social capital building, even community empowerment; Thatcher's infamously blunt 'there's no such thing as society' mutated into the smoke-andmirrors rhetoric of David Cameron's Big Society" (Peck 2013, p. 147). The adherents of the technocratic paradigm thus conceptualise social capital and community empowerment through the lens of its own key thinkers. As we have already seen, one such thinker is Schumpeter, whose thesis on creative destruction and the role of the entrepreneur, has been embraced by the technocratic school. That same thesis not only valorises the entrepreneur as the expert of the market but also valorises 'experts' of democracy, and it is at this point we can see that although messy, variegated and networked, the technocratic paradigm is underpinned by forces seeking to reinforce rather than challenge the vertical distributions of power in society.

In many ways, the adoption of Schumpeter (2011) by the technocratic school is perhaps both astute and unsurprising. In the wake of the financial crisis, it was difficult for neoliberals to deny that their project was facing real pressure and scrutiny; therefore, Schumpeter-whose analysis forlornly predicts the collapse of the capitalist system-presented neoliberals with a useful resource from a critical friend who forewarns the eventual collapse of capitalism whilst valorising its key agents, such as the entrepreneur. Moreover, the creative destruction described by Schumpeter provides the technocratic school with a theoretical pretext for the sweeping away of 'old' and 'bureaucratic' (primarily publicly owned) institutions in favour of 'new' and 'innovative' (primarily market style) programmes necessitated by austere times following the economic crisis (see Leadbeater and Meadway 2008; Bunt et al. 2010). Thus, in the technocratic school, the realm of the social becomes absorbed into a paradigm of competition.

\section{Socio-political Capacities}

The discussion surrounding the 'embeddedness' or 'disembeddedness' of markets has produced some of the most notable literature in the social sciences (Polanyi

\footnotetext{
${ }^{4} \mathrm{http}: / /$ socialstockexchange.com/.
} 
1944; Granovetter 1985) and although contributing to this debate in some detail may prove fruitful, we simply do not have the space to explore this with any justice. Instead, we shall focus upon the impact of Schumpeter's concept of 'creative destruction' on social relations which presents us with a specific case that is difficult to reconcile with any interpretation of socio-political empowerment. Nevertheless, policymakers and their advisers persist with claims that "some of the most important sectors for growth over the next few decades are linked to the development of human and social capital" (BEPA 2010, p. 15). Such claims which link social capital and economic growth not only reveals an instrumentalist interpretation of social relations which encourages the accumulation of social capital as a gateway to the accumulation of other forms of capital (see Leadbeater 1997), but also exposes a fundamental contradiction when adopting the Schumpeterian approach to social innovation. Embracing an instrumentalist approach serves to reinforce, rather than disrupt, vertical distributions of power within social relations which reflect existing inequalities (Lin 2000). For example, the exposure of workers to the dynamics of creative destruction limits their opportunities to build and maintain social relations which are disrupted by destructive market forces driven by discourses of competition that emphasise increased efficiencies and results modelled upon potential returns to investors. Nevertheless, an instrumentalist and competitive interpretation of social relations persists within this paradigm, and given the neoliberal underpinnings of the technocratic school, this understanding of empowerment through the development of a competitive self should come as no surprise (Foucault 2010; Lemke 2001). These efforts by the technocratic school to enmesh the development of subjectivities with a competitive framework can only be fully understood when analysed within a specific context and deserves the attention of scholars from a multitude of disciplines.

Nonetheless, what is already clear is that the competitive market frame embraced by the technocratic paradigm raises questions concerning its capacity to empower citizens when we consider its theoretical underpinnings in relation to social capital. The reference point of Schumpeter also unravels any potential claims that the technocratic approach is built upon theoretical perspectives which empower citizens or challenge inequalities considering that "Schumpeter was inclined to see the world from an elitarian perspective. He regarded clusters of talented people as the driving force behind economic and political history" (Giersch 1984, p. 104). Interestingly, this 'elitarian' perspective was not restricted to the economy and emerges when considering Schumpeter's analysis of the realm of the political.

What appears to be missing from the technocratic literature which adopts the Schumpeterian analysis of innovation is the theory of democracy that Schumpeter also promotes within the same thesis. Contrary to the rhetoric of empowerment so well-rehearsed by the technocratic school of social innovation, Schumpeter is a champion of the elitist theory of democracy, extending the logic of competition and markets to the realm of the political by asserting that "to simplify matters we have restricted the kind of competition for leadership which is to define democracy, to free competition for a free vote" (Schumpeter 2011, p. 271). In understanding Schumpeter's approach to democracy, we also gain further insight into his broader thesis which seeks to preserve the vertical distributions of power. Indeed, it seems 
difficult to reconcile Schumpeter with any sense of socio-political empowerment when he asserts that politics should be a profession given that the masses are a politically incapable collective whose democratic participation extends only to voting for their leaders, after which, "...they must understand that, once they have elected an individual, political action is his business and not theirs" (Schumpeter 2011 , p. 295). The technocratic paradigm of social innovation is therefore underpinned by a faith in experts such as entrepreneurs and techniques of governance which seek to displace and disguise political power as well as a commitment to the preservation and extension of the competitive neoliberal consensus which reinforces the vertical distributions of power within society.

\section{Democratic Social Innovation}

\section{The Counter-Hegemonic Paradigm}

The mobilisation of the technocratic paradigm of social innovation to shore up the neoliberal consensus has not gone unnoticed and other scholars who are also located within the field of social innovation have for some time been constructing their own paradigm within which they make reference to similar phenomena (social capital, empowerment) but, as Kuhn (1962) reminds us, these researchers see different things. Nevertheless, being adherents to one paradigm does not exclude them from analysing the motivations of those located within another. An example of this stems from Martinelli (2013) who identifies that in terms of the third way or the big society, "an ambiguous convergence has thus occurred between top-down neoliberal restructuring strategies, on the one hand, and bottom-up mobilization of users and civil society for better or more effective services on the other, which has somewhat legitimized the deregulation, liberalization and privatization processes" (p. 348). This reinforces the analysis that adherents to the different paradigms of social innovation are locked in the type of struggle which Kuhn described as a scientific revolution and compared to the characteristics of a political revolution.

The struggle between the two paradigms of social innovation is therefore firmly rooted in the nexus of existing distributions of power, in which neoliberalism is hegemonic. Nevertheless, spaces have opened up where alternative approaches to meeting human needs can be developed and which do not valorise free market thinking. As Moulaert and Nussbaumer (2005) invite us to imagine in the context of local and regional development, there is a necessity for a "broader existential ontology in which the (market) economic rationale and technological innovation are only supporting rationales" (p. 46). Indeed in a later work, Jessop and other social innovation scholars argue that "extending the social economy provides a basis for resisting capital's increasing hegemony over society as a whole" (2013, p. 118). Thus, having located where some key tensions lie, it is clear that social innovation can only be understood by recognising the socio-political struggles taking place in practice and in theory. 
A further step towards refining our understanding of the struggle taking place between the two paradigms of social innovation can be achieved by identifying the contours of the democratic social innovation paradigm which involves "countering or overcoming conservative forces that are eager to strengthen or preserve social exclusion situations" (Moulaert et al. 2013, p. 17). It should be reiterated at the outset that although this school of thought rejects the market led rationale of technocratic social innovation, this does not mean it completely eschews the economy. In fact, Moulaert and Ailenei (2005) explain that engagement with the economy can actually form part of a broader strategy; thus, they assert that "social innovation in the economy is mainly about the (re)introduction of social justice into production and allocation systems" (p. 2037). As shall be elaborated upon later in this paper, the democratic paradigm of social innovation can best be understood through the same prism of those examining the development of 'horizontalism' (Sitrin and Azzellini 2014) and those such as Gibson-Graham (2003) who perceive community economies as a "project of deconstructing the hegemony of capitalism and elaborating multiple axes of economic diversity is an emancipatory project of repoliticising the economy" (p. 126). Therefore, in contrast to the privileging by the technocratic school of the heroic entrepreneur, the democratic school represents a rejection of such hierarchical figureheads or elites, sometimes engraving this rejection into the very names of their organisations such as Fabrica Sin Patron, an exemplar of the recuperated workplace movement in Argentina (Sitrin 2012) or through the exclamations of activists in New York's Zucotti Park that 'we are the $99 \%$ ' (Graeber 2013).

Having briefly outlined the form of the emerging democratic paradigm, the question we must ask is how do adherents to this school expect their aims to be achieved? One answer can be found when considering the Integrated Area Development (IAD) framework of social innovation constructed by Moulaert et al. (2005) which reveals the emancipatory aims that can motivate the protagonists of the democratic school: seeking to meet human needs (particularly alienated needs), raising participation levels (particularly of marginalised groups) and empowerment through greater access to resources and increased social and political capacities. This discussion of increasing such capacities by Moulaert and his colleagues begins to reveal the objective of political mobilization which characterises the emerging democratic paradigm. This objective can also be identified in the notion of 'autogestion' articulated by Lefebvre (2009) whose nuanced conceptualisation of new forms of self-management recognises that they contain the potential for the construction of new democratic spaces not only in workplaces but also in communities, towns and cities (Butler 2012; Brenner 2001) whilst realising that constructing such spaces involves an ongoing struggle rather than an outcome, much like democracy itself (Elden 2004). Moreover, the critical analysis Lefebvre undertakes of the state challenges any misconception of the democratic school as simply being statist through his recognition that state support for the logic of market competition can be disguised as decentralisation or even democratisation thus preserving existing power asymmetries in society (Lefebvre 2001; Brenner 2001).

The type of participation therefore being referred to within the democratic paradigm thus reveals another point of conflict with their technocratic opponents 
who pursue a competitive neoliberalised interpretation of social relations, whereas the democratic school view social innovation, "more like a reinterpretation or reproduction of already lived social relations but within new contexts" (Moulaert and Ailenei 2005, p. 2050). We can therefore conclude that in contrast to the creative destruction of social relations ingrained within the technocratic paradigm of social innovation, the democratic paradigm is concerned with the creative transformation of social relations. Thus, empowerment through increased sociopolitical capacities has a very different meaning within the democratic paradigm as it opens, rather than closes, the possibilities for alternatives to neoliberal hegemony.

\section{The Rejection of Technocratic Governance}

The pursuit of empowerment through increased participation can be claimed by proponents of both paradigms of social innovation; however, this provides another example where each camp actually perceives and articulates different things. Rejecting the view of the technocratic paradigm which repositions citizens as consumers, those within the democratic paradigm sometimes literally describe themselves as being involved in the construction of 'other worlds'. One example of this stems from the work of Gibson-Graham and Roelvink (2013) who draw a link between the objectives of social innovation and the creation of community economies, concluding that "these innovative projects are, at the same time, projects of inclusion, whether geared towards meeting the material needs of the marginalized, opening social arenas to the previously excluded, or giving 'voice' to those who have had little or no say in political life" (p. 455). It is important to emphasise at this point that those identified as being within the democratic paradigm do not form a homogenous bloc, quite the reverse. Many of these projects will be embedded across a variety of contexts and situated within a multitude of struggles which can be described as "pockets of resistance... of all sizes, of different colours, of varying shapes" (Marcos 1997). What can thus broadly be said is that these projects embrace cooperation rather than competition and seek to organise through horizontal networks of solidarity rather than being disciplined by the market logic of technocratic neoliberal governance.

Therefore within the democratic paradigm, the objective of social innovation is to challenge those practices which continue to exclude groups and to create spaces where these groups can be heard. Adherents to the democratic paradigm confront their technocratic opponents with the assertion that "the satisfaction of basic needs cannot be guaranteed through either competitive market allocation mechanisms, or free-market democracy" (Moulaert and Nussbaumer 2005, p. 50). Moreover, the democratic school have demonstrated an awareness of how socially innovative organisations and initiatives which may offer an alternative to neoliberalised solutions are themselves at risk of being co-opted by the technocratic paradigm through neoliberal conducts of governance. Indeed, it would be an act of hubris to discount the possibility that the efforts of researchers and policymakers may also be exposed to the same risk.

Concerns regarding organisations being co-opted are voiced by Jessop (2002) who highlights the strategic role of the social economy or third sector in sustaining 
neoliberalism through the deployment of a flanking strategy-neocommunitarianism-which is "linked to attempts to manage issues of social exclusion and social cohesion at the urban level even in the most neoliberal cases" (p. 464). In response to this analysis, Gerometta et al. (2005) argue that civil society should not supersede the state at a local level but instead should only ever be there to support it; indeed, these researchers argue that "truly public, and local social economy experiences need welfare state support" (p. 2008). Moreover, the defence of welfare state support does not mean that democratic social innovation scholars should be described as 'statist', but instead are expressing concerns that the capture of social innovation by the technocratic paradigm must be opposed especially when the result is that "social innovation becomes an alibi for the state to abdicate its social responsibility while cutting public spending" (Martinelli 2013, p. 356). These concerns relate to an increasingly complex landscape in the governance of many states which can best be understood through the lens of what Foucault (2010) identified as neoliberal governmentality.

The link between the technocratic paradigm of social innovation and neoliberal governmentality is addressed in some detail by Swyngedouw (2005) who concludes that these new forms of governance do not represent a decline of state power as they are in fact mostly instituted and controlled by the state. He argues that the state mobilises governance as a method of maintaining its own legitimacy in times of crisis and pursuing policies which would normally meet resistance from civil society actors. Moreover, within the context of austerity and ever deceasing pools of public funded support, many civil society actors find themselves enmeshed within forms of governance which force them to compete to be efficient service delivery providers that play by the rules of the neoliberal game. Consequently, the technologies of 'governance' are presented as a gateway towards civil society empowerment when in fact these represent a Trojan horse for reducing the space of the political and consolidating the primacy of the market (Wilson and Swyngedouw 2014). This concern echoes the conclusion of Moulaert and Nussbaumer (2005) that "the satisfaction of basic needs is scarcely present in contemporary national political agendas, which are increasingly oriented towards 'pleasing the free market' by deregulating and regulating in favour of free-riding capital and profit-oriented competition" (p. 50). These analyses further clarify the existence of two paradigms of social innovation which are in conflict: a struggle between a technocratic paradigm imbued with a neoliberal doxa which "seeks the end of politics" (Chambers 2012, p. 73) through the technologies of governance and another democratic paradigm which seeks to disrupt the neoliberal consensus and politicise those spaces which have been devoid of politics.

\section{Socio-political Capacities}

When returning to the question of whether or not social innovation paradigms are incommensurable, we must confront the issue of which type of interactions are actually possible between these schools of thought. Although the initial thesis of incommensurability outlined by Kuhn suggested that little dialogue between paradigms was possible, in later works, he revises this position to suggest that 
although interaction between paradigms is difficult, it is not impossible: "in applying the term incommensurability to theories, I had intended only to insist that there was no common language within which both could be fully expressed and which could therefore be used in a point-by-point comparison between them" (Kuhn 1976, p. 191). The discursive emphasis articulated by Kuhn strikes at the very heart of our analysis of the development of a democratic social innovation paradigm, by recalling the comparison that Kuhn made between scientific and political revolutions. It is through the political act of articulating voice, being heard-or more importantly-being understood, that we can understand how the democratic paradigm of social innovation challenges its technocratic counterpart.

The connection between expressing Voice and the fundamentals of democracy stretch back millennia to the works of Aristotle, but in contemporary times the work of Jacques Ranciere has reasserted the importance of such simple, but powerful acts. Ranciere (2004) cites the work of French nineteenth century writer Ballanche when recalling the actions of the plebeians on the Aventine Hill in ancient Rome who demanded a treaty with the patricians and were met by the response that the plebeians were capable only of noise rather than speech, which could be exercised only by free men. Therefore, the articulation of Voice is inextricably linked to the enacting of democracy since it is "the speech of those who should not be speaking, those who were not really speaking beings" (Ranciere 2004, p. 5). The relevance of the discursive turn by Kuhn (1976) concerning the application of the concept of incommensurability to the paradigms we have identified becomes ever more apparent when considering the analysis by Ranciere regarding the centrality of Voice. Nevertheless, even being understood is not enough for democracy to be enacted, for this to be achieved Ranciere argues that there must be disagreement, an "instituting of a quarrel that challenges the incorporated, perceptible evidence of an inegalitarian logic. This quarrel is politics" (2004, p. 5). Therefore, it is politics which produces the space which enables, at the very least, interaction between the two emergent paradigms of social innovation we have identified.

The politics which Ranciere describes offers the prospect of an enhanced understanding of the conflict which exists between social innovation paradigms as "politics is primarily conflict over the existence of a common stage and over the existence and status of those present on it" (1999, pp. 26-27). This common stage is brought about by those - such as the plebeians of ancient Rome-who previously had no Voice, asserting a place in the order of things. Indeed as Ranciere clarifies: "the essence of politics is the manifestation of dissensus, as the presence of two worlds in one" (2001, Thesis 8). This description captures precisely the thrust of our analysis, that the developing paradigmatic worlds of technocratic and democratic social innovation cannot be subjected to the measurement of a comparative evaluation but can interact through the rupture caused by the adherents of the democratic school demanding to be heard as equals of those adhering to a technocratic school supported by the advocates and technologies of neoliberal hegemony. We obviously cannot expect any rupture to be welcomed by the technocratic paradigm; indeed, just as Kuhn (1962) explains that anomalies which do not fit with a paradigm are ignored by its adherents, or as Ranciere (2004) describes the actions of the patricians of ancient Rome in dismissing and ignoring 
the demands of the plebeians, so too can we expect a similar response directed towards the democratic school of social innovation by their technocratic counterparts. However, we must ask how such ignorance is made possible and in what ways it may be sustained.

It is Ranciere who offers a valuable way to understand how adherents to the nascent neoliberalised technocratic paradigm will have developed their own ontology and how they will seek to maintain it. For Ranciere (2001), the police (or what he also refers to as the partition of the sensible) distributes spaces and functions within society and thus determines who is seen and who can be heard (or more specifically, who can be understood). Therefore, in terms of the technocratic school of social innovation, that which is sensible consists of those initiatives which are co-opted by neoliberal governmentality and its experts, those organisations which embrace the marketised framing of the 'social good' and those individuals who epitomise the narrative of the 'heroic entrepreneur' amongst others. Of relevance here is Ranciere's claim that the 'partitioning of the sensible'-much like the neoliberalisation described by Peck et al. (2010)-is never complete. Not everyone is assigned a place or is 'heard'; thus, Ranciere describes those who are outside the distribution of the sensible as those who have no part, those who are neither seen nor 'heard' by the police.

Just as the technocratic paradigm constructs roles and functions and gives a place to certain organisations and initiatives whilst claiming it has been inclusive, so too there exist those organisations which are excluded, those initiatives which are not counted and it is these groups and those initiatives which 'have no part' to borrow Ranciere's phrase, which may be attracted to the democratic social innovation paradigm and which threaten to disrupt the neoliberal consensus shored up by the technocratic social innovation paradigm. In other words, "if a social innovation wants to become radical, it has to react to the overall constitution of societal organization in which old and new forms of authoritarianism are intertwined" (Novy and Hammer 2007, p. 211). These social innovations which find themselves to be outsiders are those which have not only refused to accept the technocratic paradigm but also reject the neoliberalisation which informs it and as a consequence may find that they are dismissed as radicals or extremists who are "relegated to a domain outside the consensual post-democratic arrangement; they are rendered inexistent" (Swyngedouw 2014, p. 177). Nevertheless, it is their very exclusion which may also provide the space within which these groups may be able to organise and coalesce around common goals; in other words, "the partition excludes, and at the same time it makes a new form of participation possible" (Chambers 2012, p. 70).

The idea that the space for the democratic paradigm emerges as a result of the exclusion of a group or section of society bears a striking resemblance to broader analyses of the development of opposition to the neoliberal doxa which informs the technocratic paradigm where the processes of "deep neoliberalization has created new basing points, strategic targets and weak spots" (Peck and Tickell 2002, p. 399). It is for this reason that the significance of social innovation as a battleground between paradigms becomes increasingly apparent as it is in this area where neoliberalisation is theoretically and practically at its most vulnerable. One 
example of this surfaced amidst the collapse of Spain's housing bubble, with the shortcomings of financial speculation resulting in the emergence of Plataforma de Afectados por la Hipoteca ${ }^{5}$ which has campaigned against the evictions of families, reasserting housing as a basic need rather than a profitable investment. These weaknesses of neoliberalism perhaps also explain the interest and support from neoliberal governments and institutions for the technocratic paradigm which can be mobilised to shore up the neoliberal consensus in times of crisis. The technocratic paradigm of social innovation is therefore activated to protect these vulnerabilities, and one way it does this is by depoliticising issues and spaces where neoliberalism is at its most anomalous.

Just as Kuhn explained that the adherents to an established paradigm will seek to explain away or even ignore those anomalies which threaten to undermine it, neoliberals have proactively mobilised the technocratic paradigm of social innovation, recognising that it can neatly mirror the broader processes of neoliberalisation which are "increasingly technocratic in form and therefore superficially 'depoliticized', acquiring the privileged status of a taken-for-granted or foundational policy orientation" (Peck and Tickell 2002, p. 389). The technocratic social innovation paradigm thus offers the capacity to subvert potential dissent through the depoliticisation of issues which may expose the fallibility of neoliberalism. Given the spatial focus of social innovation, it will carry out this depoliticisation in the very poorest and most marginalised communities where the contradictions of neoliberal logic are laid bare. As Ranciere explains, depoliticisation supports the prevailing consensus by quelling contention, and consequently, rather than spaces of politics being opened, the discourse is characterised by "asking experts for solutions, and to discussing them with representatives qualified in grand social interests" (Ranciere 2014, p. 58). This often leads to the type of reductionism we have outlined above in the identification of the nascent technocratic social innovation paradigm, where those needs and problems which have the potential to spark politicisation are in fact converted to the depoliticised domain of neoliberal economics (Wilson and Swyngedouw 2014). In contrast, the democratic paradigm offers the possibility for social innovation to increase the socio-political capacities of the most excluded citizens by transforming uncontested issues into spaces for politics and by mobilising the very communities whose voices are not heard.

\section{Conclusions}

Adopting a paradigmatic analysis, we have identified two schools of social innovation-technocratic and democratic-which are currently engaged in a struggle to ultimately define the concept. This has presented us with a clearer picture of the characteristics of each paradigm and the motivations of policymakers, practitioners and academics who advocate from within each school. The technocratic paradigm, with its neoliberal foundations, espouses rhetoric based upon the

\footnotetext{
5 http://afectadosporlahipoteca.com/.
} 
empowerment of communities but in its actions valorises the role of the expert, mobilising the technologies of governance to reduce the space for political dissent. Despite its claims being articulated under the rubric of participation, we hypothesise that its outcomes will only serve to entrench the existing vertical distributions of power in society. The democratic paradigm advocated by those who wish to subvert and disrupt neoliberalism embraces not only the participation of communities but also perceives the knowledge produced within them as being of equal merit to 'experts' (Moulaert and Van Dyck 2013; Moulaert et al. 2013; Jessop et al. 2013; Ranciere 1991). Moreover, the democratic school conceive social innovation as being a tool for politicising the very spaces which neoliberals have sought to depoliticise, challenging the vertical distributions of power in society and seeking to disrupt and replace them with horizontal alternatives.

Given the paradigmatic analysis outlined above and the insistence from Kuhn (1962) that no research can be paradigm independent, it is perhaps important to confirm that this analysis does not occupy an Archimedean point and is itself enmeshed within the struggle between both schools of thought. Even though this analysis perceives the world through the prism of the democratic paradigm, this does not prevent us from locating the key terrains upon which this struggle takes place. Indeed, returning to Kuhn, we can see from his later works on incommensurability that he refined the concept further, finding that "only for a small subgroup of (usually interdefined) terms and for sentences containing them do problems of translatability arise" (Kuhn 1982, pp. 670-671). Therefore, in the paradigmatic war between democratic and technocratic schools, we witness these problems of translation when speaking of social capital, empowerment and social innovation itself.

The paradigmatic analysis outlined thus far has helped us to identify some of the key concepts which may escape translation between the different schools; however, it is impossible to develop a more nuanced analysis without considering that social innovation "cannot be separated from either its socio-cultural, or from its socialpolitical context" (Moulaert et al. 2013, p. 17). Therefore, it is only through the study of local struggles shall we develop a better understanding of which paradigm is succeeding in the battle to define social innovation.

\section{Compliance with Ethical Standards}

Conflict of interest The author declares that he has no conflict of interest.

Open Access This article is distributed under the terms of the Creative Commons Attribution 4.0 International License (http://creativecommons.org/licenses/by/4.0/), which permits unrestricted use, distribution, and reproduction in any medium, provided you give appropriate credit to the original author(s) and the source, provide a link to the Creative Commons license, and indicate if changes were made.

\section{References}

Bockman, J. (2012). The political projects of neoliberalism. Social Anthropology, 20(3), 310-317.

Borzaga, C., \& Defourny, J. (2001). The emergence of social enterprise (Vol. 4). Philadelphia: Psychology Press. 
Brenner, N. (2001). State theory in the political conjuncture: Henri Lefebvre's "Comments on a new state form". Antipode, 33(5), 783-808.

Brenner, N., \& Theodore, N. (2002). Cities and the geographies of "Actually Existing Neoliberalism". Antipode, 34(3), 349-379.

Bunt, L., Harris, M., \& Westlake, S. (2010). Schumpeter comes to Whitehall. London: NESTA.

Bureau of European Policy Advisors (BEPA). (2010). Empowering people, driving change: Social innovation in the European union. Luxembourg: Publications Office of the European Union.

Butler, C. (2012). Henri Lefebvre: Spatial politics, everyday life and the right to the city. New York: Routledge.

Cajaiba-Santana, G. (2014). Social innovation: Moving the field forward. A conceptual framework. Technological Forecasting and Social Change, 82, 42-51.

Caulier-Grice, J., Davies, A., Patrick, R., and Norman, W. (2012). Defining social innovation. A deliverable of the project: "The theoretical, empirical and policy foundations for building social innovation in Europe" (TEPSIE). European Commission-7th Framework Programme, Brussels: European Commission, DG Research.

Chambers, S. (2012). The lessons of Ranciere. Oxford: Oxford University Press.

Dawson, P., \& Daniel, L. (2010). Understanding social innovation: A provisional framework. International Journal of Technology Management, 51(1), 9-21.

Dees, J.G. (2001). The meaning of 'Social Entrepreneurship'. Center for the Advancement of Social Entrepreneurship.

Dees, J. G., \& Economy, P. (2002). Social entrepreneurship. In J. G. Dees, J. Emerson, \& P. Economy (Eds.), Enterprising nonprofits: A toolkit for social entrepreneurs (Vol. 186). New York: Wiley.

Dowling, E., \& Harvie, D. (2014). Harnessing the social: State, society and (big) society. Sociology, 48(5), 869-886.

Elden, S. (2004). Understanding Henri Lefebvre. UK: A\&C Black.

Foucault, M. (2010). The birth of biopolitics: Lectures at the College De France, 1978-1979 (Lectures at the College De France). Basingstoke: Palgrave Macmillan.

Gabriel, M. (2014). Strategies for scaling social innovations. London: NESTA.

Gerometta, J., Haussermann, H., \& Longo, G. (2005). Social innovation and civil society in urban governance: Strategies for an inclusive city. Urban Studies, 42(11), 2007-2021.

Gibson-Graham, J. K. (2003). Enabling ethical economies: Cooperativism and class. Critical Sociology, 29(2), 123-161.

Gibson-Graham, J. K., \& Roelvink, G. (2013). Social innovation for community economies: How action research creates 'other worlds'. In F. Moulaert, D. MacCallum, A. Mehmood, \& A. Hamdouch (Eds.), The international handbook on social innovation: Collective action, social learning and transdisciplinary research (pp. 466-480). Cheltenham: Edward Elgar.

Giersch, H. (1984). The age of Schumpeter. The American Economic Review, 74, 103-109.

Graeber, D. (2013). The democracy project: A history, a crisis, a movement. New York: Spiegel \& Grau.

Granovetter, M. (1985). Economic action and social structure: The problem of embeddedness. American Journal of Sociology, 91(3), 481-510.

Hood, C. (1991). A public management for all seasons? Public Administration, 69(1), 3-19.

Jessop, B. (2002). Liberalism, neoliberalism, and urban governance: A state-theoretical perspective. Antipode, 34(3), 452-472.

Jessop, B., Moulaert, F., Hulgard, L., \& Hamdouch, A. (2013). Social innovation research: A new stage in innovation analysis? In F. Moulaert, D. MacCallum, A. Mehmood, \& A. Hamdouch (Eds.), The international handbook on social innovation: Collective action, social learning and transdisciplinary research (pp. 110-130). Cheltenham: Edward Elgar.

Kuhn, T. S. (1962). The structure of scientific revolutions. Chicago: University of Chicago Press.

Kuhn, T. S. (1970). 'Postscript in', the structure of scientific revolutions (2nd ed.). University of Chicago Press: Chicago.

Kuhn, T. S. (1976). Theory-change as structure-change: Comments on the Sneed formalism. Erkenntnis, 10, 179-199.

Kuhn, T.S. (1982) Commensurability, comparability, communicability. In PSA: Proceedings of the biennial meeting of the philosophy of science association, (Vol. 2, pp. 669-688). Symposia and Invited Papers.

Larrson, O. S., \& Brandsen, T. (2016). The implicit normative assumptions of social innovation research: Embracing the dark side. In T. Brandsen, S. Cattacin, A. Evers, \& A. Zimmer (Eds.), Social innovation in the urban context. Berlin: Springer. 
Le Grand, J. (2006). Motivation, agency, and public policy: of knights and knaves, pawns and queens. OUP Catalogue.

Leadbeater, C. (1997). The rise of the social entrepreneur. London: Demos.

Leadbeater, C., and Meadway, J. (2008). Attacking the recession: How innovation can fight the downturn. NESTA Discussion Paper.

Lefebvre, H. (2001). Comments on a new state form. Translated by Victoria Johnson and Neil Brenner. Antipode, 33(5), 769-782.

Lefebvre, H. (2009). State, space, world: Selected essays. Minneapolis: University of Minnesota Press.

Lemke, T. (2001). 'The birth of bio-politics': Michel Foucault's lecture at the Collège de France on neoliberal governmentality. Economy and Society, 30(2), 190-207.

Lin, N. (2000). Inequality in social capital. Contemporary Sociology, 29(6), 785-795.

Marcos, S. (1997). The fourth world war has begun. Le Monde Diplomatique. https://mondediplo.com/ 1997/09/marcos.

Martinelli, F. (2013). Learning from case studies of social innovation in the field of social services: Creatively balancing top-down universalism with bottom-up democracy. In F. Moulaert, D. MacCallum, A. Mehmood, \& A. Hamdouch (Eds.), The international handbook on social innovation: Collective action, social learning and transdisciplinary research (pp. 346-360). Cheltenham: Edward Elgar.

Masterman, M. (1970). The nature of a paradigm. In I. Lakatos \& A. Musgrave (Eds.), Criticism and the growth of knowledge. London: Cambridge University Press.

McHugh, N., Sinclair, S., Roy, M., Huckfield, L., \& Donaldson, C. (2013). Social impact bonds: a wolf in sheep's clothing? Journal of Poverty and Social Justice, 21(3), 247-257.

Moulaert, F., \& Ailenei, O. (2005). Social economy, third sector and solidarity relations: A conceptual synthesis from history to present. Urban Studies, 42(11), 2037-2053.

Moulaert, F., MacCallum, D., \& Hillier, J. (2013). Social innovation: Intuition, precept, concept, theory and practice. In F. Moulaert, D. MacCallum, A. Mehmood, \& A. Hamdouch (Eds.), The international handbook on social innovation: Collective action, social learning and transdisciplinary research (pp. 13-24). Cheltenham: Edward Elgar.

Moulaert, F., Martinelli, F., Swyngedouw, E., \& Gonzalez, S. (2005). Towards alternative model(s) of local innovation. Urban Studies, 42(11), 1969-1990.

Moulaert, F., \& Nussbaumer, J. (2005). The social region beyond the territorial dynamics of the learning economy. European Urban and Regional Studies, 12(1), 45-64.

Moulaert, F., \& Van Dyck, B. (2013). Framing social innovation research: A sociology of knowledge perspective. In F. Moulaert, D. MacCallum, A. Mehmood, \& A. Hamdouch (Eds.), The international handbook on social innovation: Collective action, social learning and transdisciplinary research (pp. 13-24). Cheltenham: Edward Elgar.

Mulgan, G. (2006). The process of social innovation. Innovations: Technology, Governance, Globalization, $1(2), 145-162$.

Mulgan, G. (2007). In and out of sync: The challenge of growing social innovations. London: NESTA.

Murray, R., Caulier-Grice, J., \& Mulgan, G. (2010). The open book of social innovation. London: NESTA.

Nicholls, A. (2010). The legitimacy of social entrepreneurship: Reflexive isomorphism in a preparadigmatic field. Entrepreneurship Theory and Practice, 34(4), 611-633.

Nicholls, J., Lawlor, E., Neitzert., E., and Goodspeed, T. (2009). A guide to social return on investment. Cabinet Office for the Third Sector.

Nicholls, A., \& Murdock, A. (2012). The nature of social innovation. In A. Nicholls \& A. Murdock (Eds.), Social innovation: Blurring boundaries to reconfigure markets (pp. 1-30). Basingstoke and New York: Palgrave Macmillan.

Nicholls, A., Simon, J., \& Gabriel, M. (2015). Introduction: Dimensions of social innovation. In A. Nicholls, J. Simon, \& M. Gabriel (Eds.), New frontiers in social innovation research. Basingstoke: Palgrave Macmillan.

Novy, A., \& Hammer, E. (2007). Radical innovation in the era of liberal governance the case of Vienna. European Urban and Regional Studies, 14(3), 210-222.

Osborne, D., \& Gaebler, T. (1992). Reinventing government: How the entrepreneurial spirit is transforming government. Reading: Adison Wesley Public Comp.

Pearce, J. (2003). Social enterprise in anytown. London: Calouste Gulbenkian Foundation.

Peck, J. (2008). Remaking laissez-faire. Progress in Human Geography, 32(1), 3-43.

Peck, J. (2013). Explaining (with) neoliberalism. Territory, Politics, Governance, 1(2), 132-157. 
Peck, J., Theodore, N., \& Brenner, N. (2010). Postneoliberalism and its malcontents. Antipode, 41(s1), 94-116.

Peck, J., \& Tickell, A. (2002). Neoliberalizing space. Antipode, 34(3), 380-404.

Peredo, A. M., \& McLean, M. (2006). Social entrepreneurship: A critical review of the concept. Journal of World Business, 41(1), 56-65.

Phills, J. A., Deiglmeier, K., \& Miller, D. T. (2008). Rediscovering social innovation. Stanford Social Innovation Review, 6(4), 34-43.

Polanyi, K. (1944). The great transformation: The political and economic origins of our time. New York: Rinehart.

Ranciere, J. (1991). The ignorant schoolmaster: Five lessons in intellectual emancipation. Stanford: Stanford University Press.

Rancière, J. (1999). Disagreement, trans. Julie Rose. Minneapolis: University of Minnesota Press.

Rancière, J. (2001). Ten theses on politics. Theory \& Event. 5(3).

Rancière, J. (2004). Introducing disagreement 1. Angelaki: Journal of the Theoretical Humanities, 9(3), 3-9.

Rancière, J. (2014). Hatred of democracy. London and New York: Verso.

Reeder, N., O’ Sullivan, C., Tucker, S. Ramsden, P., and Mulgan, G. (2012). Strengthening social innovation in Europe: Journey to effective assessment and metrics. Directorate-General for Enterprise and Industry.

Schumpeter, J. (2011). Capitalism, socialism, and democracy. New York: Martino. [1947].

Schwab Foundation. (2013). Breaking the binary: Policy guide to scaling social innovation. Geneva.

Sharrock, W., \& Read, R. (2002). Kuhn: Philosopher of scientific revolutions. Cambridge: Polity Press.

Sinclair, S., \& Baglioni, S. (2014). Social innovation and social policy-promises and risks. Social Policy and Society, 13(03), 469-476.

Sitrin, M. (2012). Everyday revolutions: Horizontalism and autonomy in Argentina. London and New York: Zed Books.

Sitrin, M., \& Azzellini, D. (2014). They can't represent us!: Reinventing democracy from Greece to occupy. London and New York: Verso.

Swyngedouw, E. (2005). Governance innovation and the citizen: The janus face of governance-beyondthe-state. Urban Studies, 42(11), 1991-2006.

Swyngedouw, E. (2014). Insurgent architects, radical cities and the promise of the political. In E. Swyngedouw \& J. Wilson (Eds.), The post-political and its discontents: Spaces of de-politicization, specters of re-politicization. Edinburgh: Edinburgh University Press.

Teasdale, S. (2012). What's in a name? Making sense of social enterprise discourses. Public Policy and Administration, 27(2), 99-119.

Unger, R. M. (2015). Conclusion: The task of the social innovation movement. In A. Nicholls, J. Simon, \& M. Gabriel (Eds.), New frontiers in social innovation research. Basingstoke: Palgrave Macmillan.

Wilson, J., \& Swyngedouw, E. (2014). Post-politics and the return of the political. In E. Swyngedouw \& J. Wilson (Eds.), The post-political and its discontents: Spaces of de-politicization, specters of repoliticization. Edinburgh: Edinburgh University Press.

European Commission. (2013). Guide to social innovation. DG Regional and Urban Policy and DG Employment, Social affairs and Inclusion. 